\title{
Human-derived acellular dermal matrix may be an alternative to autologous grafts in tympanic membrane reconstruction: systematic review and meta-analysis
}

Shan Xu, Xia Sun, Ning Yang and Aihui Yan *io

\begin{abstract}
Background: Human-derived acellular dermal matrix (ADM) has been widely used as an effective alternative to autologous grafts in tympanoplasty. However, evidence of ADM as an alternative to autologous grafts in the repair of tympanic membrane (TM) perforation still lacks adequate empirical evidence.

Objectives: To determine the clinical safety and efficacy of human-derived ADM as TM graft material for tympanoplasty.

Data sources: The PubMed, EMBASE, Cochrane Library, EBSCO, Ovid, Scopus, and Web of Science databases and reference lists of the retrieved articles were searched, with no language restriction.

Selection criteria: All randomized controlled trials and retrospective cohort studies that compared the use of human-derived ADM and autologous grafts in tympanoplasty for TM perforation were included.

Data collection and analysis: Two review authors independently assessed risk of bias in the included studies and extracted data. The pooled results for continuous data were reported as a mean difference (MD) and 95\% confidence intervals (CI). For dichotomous data, odds risk (OR) with $95 \% \mathrm{Cl}$ was used. Chl ${ }^{2}$ statistic and Galbraith plots were used to assess the heterogeneity. Publication bias was assessed with a funnel plot and Egger's test.

Main results: Five retrospective cohort studies and four randomized controlled studies with a total of 610 participants were included in the meta-analysis. No significant differences in graft success (OR: $0.71[0.39,1.29], p=$ 0.26), air-bone gap (ABG) reduction (MD: $-0.59[-3.81,1.19], p=0.51)$, or complications (OR: 1.23 [0.07, 20.64], $p=$ 0.89) were found between the ADM group and autologous graft group. The use of ADM significantly shortened tympanoplasty surgery time (MD: $-16.14[-21.22,-11.07], p<0.00001)$ and reduced postoperative pain (MD: -2.57 $[-3.57,-1.58], p<0.00001)$ compared with the autologous graft group.

Conclusion: Human-derived ADM might be an effective alternative to autologous grafts for tympanoplasty. However, some of the studies that were included in the present meta-analysis had rather low methodological quality, and more adequately designed clinical trials should be performed in the future.
\end{abstract}

Keywords: Acellular dermal matrix, Autologous grafts, Tympanoplasty

* Correspondence: yanaihui567@sina.com

Department of Otolaryngology, The First Hospital of China Medical

University, Shenyang, Liaoning 110001, People's Republic of China

(c) The Author(s). 2021 Open Access This article is licensed under a Creative Commons Attribution 4.0 International License, which permits use, sharing, adaptation, distribution and reproduction in any medium or format, as long as you give appropriate credit to the original author(s) and the source, provide a link to the Creative Commons licence, and indicate if changes were made. The images or other third party material in this article are included in the article's Creative Commons licence, unless indicated otherwise in a credit line to the material. If material is not included in the article's Creative Commons licence and your intended use is not permitted by statutory regulation or exceeds the permitted use, you will need to obtain permission directly from the copyright holder. To view a copy of this licence, visit http://creativecommons.org/licenses/by/4.0/. The Creative Commons Public Domain Dedication waiver (http://creativecommons.org/publicdomain/zero/1.0/) applies to the data made available in this article, unless otherwise stated in a credit line to the data. 


\section{Background}

Tympanic membrane (TM) perforation is a common health issue in otolaryngology. Tympanic membrane perforation is usually caused by trauma, chronic otitis media, or surgical complications and presents with conductive hearing loss [1]. Although most TM perforations heal spontaneously, some patients require surgery [2].

Tympanoplasty involves surgical repair of the TM. Tympanoplasty was introduced in the 1950s [3]. Different types of graft materials have been used to reconstruct the TM, including temporalis fascia, cartilage perichondrium, adipose tissue, muscle fascia, and scar tissue [4-7]. The temporalis fascia and tragal perichondrium are the most commonly used graft materials, with a good success rate for TM reconstruction [8-11]. However, additional incisions are required during surgery to harvest these materials, which consequently increases patient suffering and the risk of postoperative infection.

Acellular dermal matrix (ADM) is a soft tissue graft that is created by the decellularization of tissue, leaving the extracellular matrix. The dermal surface of ADM is favorable for the growth of epithelial cells and vascularization, which can help achieve rapid epithelialization [12]. As cellular components of the epidermis and dermis are removed, ADM can be tolerated in the host without triggering an immune response. Additionally, ADM is produced under aseptic conditions to ensure that the allograft is sterile and free of viruses, bacteria, and spores. A cellular dermal matrix has long been used as a soft tissue replacement, and it is commonly used in the field of wound healing, tissue repair, and reconstruction [13]. In recent years, ADM has also been widely used as graft material in tympanoplasty [14].

Animal studies showed that ADM exhibits excellent closure rates in repairing induced TM perforations compared with autologous grafts [15-18]. Recent clinical trials have also demonstrated the efficacy of ADM in the repair of TM perforations. The use of ADM to repair TM perforations is promising because it is readily available and relatively easy to apply [19-21]. Acellular dermal matrix was shown to be an effective alternative to autologous grafts in some randomized controlled trials [22-25]. Retrospective studies also confirmed these success rates, and hearing improvements were similar for ADM and autologous grafts for tympanoplasty [8, 26-29].

However, evidence of ADM as an alternative to autologous grafts in the repair of tympanic membrane (TM) perforations still lacks adequate empirical evidence. Therefore, we performed a meta-analysis of comparative studies to determine the clinical safety and efficacy of ADM as TM graft material for tympanoplasty.

\section{Methods}

This meta-analysis was performed according to Preferred Reporting Items for Systematic Reviews and
Meta-Analyses (PRISMA) guidelines for meta-analyses of intervention trials.

\section{Types of studies}

Randomized controlled trials and retrospective cohort studies that compared the use of ADM and autologous grafts in tympanoplasty for TM perforations were included in the present meta-analysis. The included studies had to be published as full papers. Studies that reported results only as abstracts were not included.

\section{Types of participants}

Patients who underwent tympanoplasty for TM perforations that were caused by trauma, chronic otitis media, or middle ear cholesteatoma were included in the metaanalysis.

\section{Types of interventions}

Interventions of interest included those that used ADM or autologous grafts, such as temporalis fascia, tragal perichondrium, and mastoid process periosteum, for TM grafting in tympanoplasty.

\section{Inclusion and exclusion criteria}

The outcomes included graft success rate, surgery time, postoperative pain, hearing gain, and complications. The inclusion criteria were (1) randomized controlled trials or retrospective cohort studies, (2) only adult patients, and (3) patients who underwent type I tympanoplasty. The exclusion criteria included (1) pediatric patients, (2) patients who underwent ossicular chain reconstruction, and (3) patients who underwent type 3 tympanoplasties or other ossicular procedures.

\section{Outcome and measures}

Graft success was defined as closure of the TM perforation within the follow-up period. Surgery time was defined as the interval between the time of ear speculum insertion into the ear canal and time of postoperative dressing application. Postoperative pain was measured using a $10 \mathrm{~cm}$ visual analog scale (VAS), which consisted of a $10 \mathrm{~cm}$ long horizontal line, marked from 0 on the left to 10 on the right, with 0 representing no pain and 10 denoting the highest possible pain intensity. This VAS has been demonstrated to be a reliable method of self-rating pain intensity. Audiometric outcomes were measured using pure-tone auditory tests, air conduction (AC) thresholds, bone conduction (BC) thresholds, and air-bone gap (ABG) to evaluate hearing gain. Complications were defined as all adverse events that were related to the intervention that occurred during the follow-up period. 


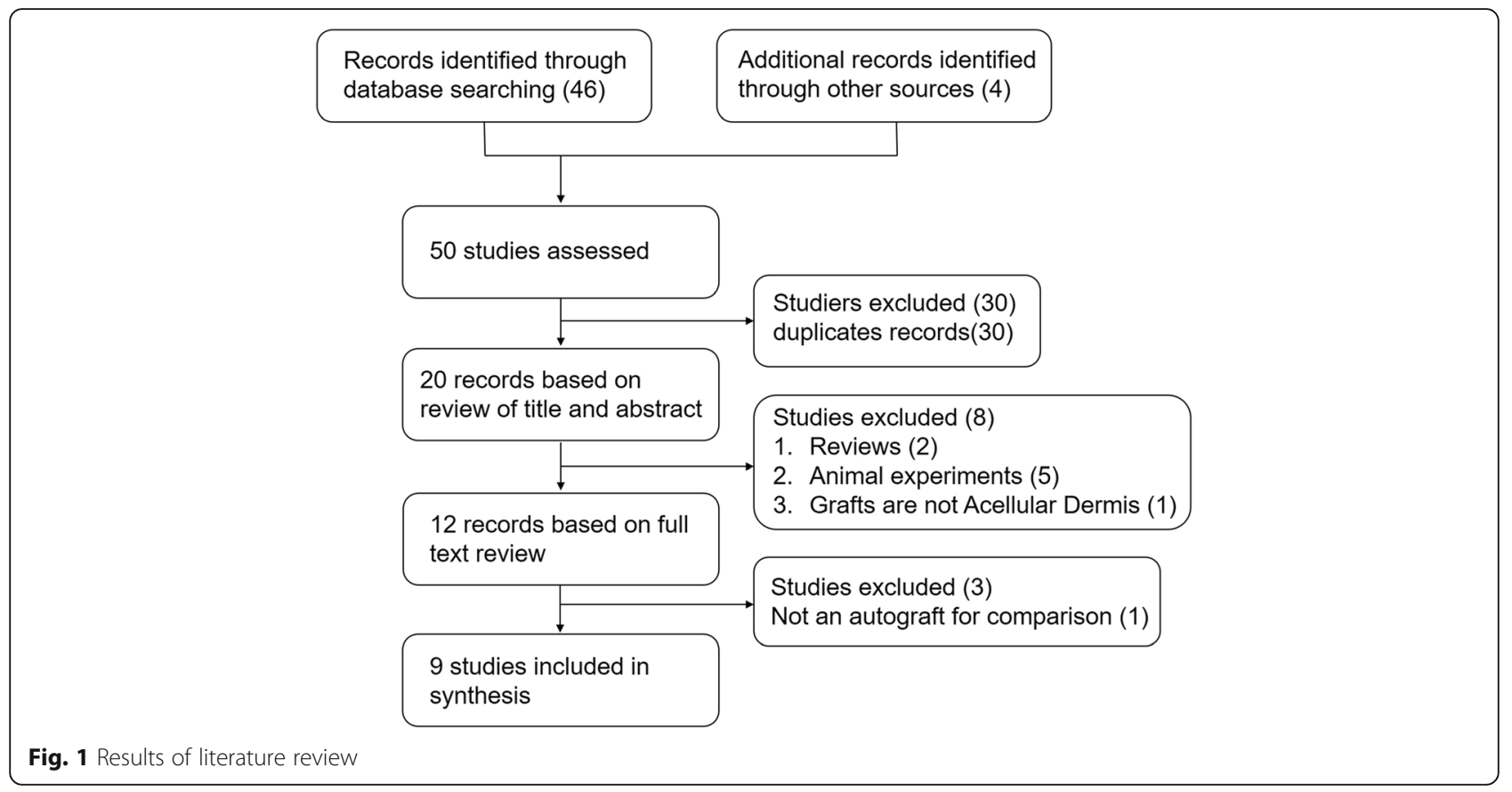

\section{Data sources and search strategy}

We searched the PubMed, EMBASE, Cochrane Library, EBSCO, Ovid, Scopus, and Web of Science databases for all articles since the databases' inception to October 2020. We also searched the retrieved articles' reference lists, with no language restriction. The searches were conducted using controlled search terms. We searched both titles and abstracts. The search terms were the following: (acellular dermis OR acellular dermal tissue OR acellular dermal graft tissue OR decellularized dermal scaffold OR acellular dermal matrix) AND (tympanoplasty OR tympanoplasties). A full description of the search strategy is presented in Additional File 1.

\section{Selection of studies}

Two authors of the present meta-analysis independently read the titles and abstracts of the articles that were retrieved based on the search terms. Two authors independently retrieved and evaluated the full text of the potentially relevant studies. Any disagreements among the authors about the eligibility of articles were discussed and resolved collectively to determine the articles' ultimate eligibility for inclusion in the analysis.

\section{Data extraction and management}

We prepared a data extraction form for data extraction. Two authors extracted the data, and any differences in the extracted data among the authors' completed forms were subsequently reviewed by a third author until agreement was reached.

\section{Risk of bias assessment}

Methodological quality was assessed by two authors independently. The risk of bias of the randomized controlled trials was assessed using the Cochrane risk of bias tool. This tool consists of domains of sequence generation, allocation concealment, blinding of participants and personnel, blinding of outcome assessors, incomplete outcome data, selective reporting, and other sources of bias. Each domain was rated as low, unclear, or high risk. Nonrandomized controlled trials were assessed using the Newcastle-Ottawa Quality Assessment Scale. This scale consists of domains of selection, comparability, and outcome. It identifies "high" quality choices with stars for every domain, with a maximum of eight stars per study.

\section{Statistical analysis}

We performed the data synthesis and statistical analysis using Review Manager software. For continuous data, we used the mean and standard deviation (SD) that were reported in the original study. Pooled results for continuous data are reported as the mean difference (MD) and 95\% confidence interval (CI). For dichotomous data, we used odds risk (ORs) and 95\% CI.

$\mathrm{ChI}^{2}$ statistic was used to assess heterogeneity among trials. We regarded heterogeneity as substantial if $\mathrm{I}^{2}>$ $50 \%$. Galbraith plots were used to explore potential sources of heterogeneity. If clinical heterogeneity was found, then pooled outcomes were calculated using random-effects meta-analysis. For all other analyses, fixed-effect meta-analysis was used for combining data.

Because we included randomized controlled trials and retrospective cohort studies, we conducted a subgroup 
Table 1 Characteristics of the include studies

\begin{tabular}{|c|c|c|c|c|c|c|c|}
\hline \multirow[t]{2}{*}{ Study } & \multirow[t]{2}{*}{ Design } & \multirow[t]{2}{*}{ Participants } & \multicolumn{2}{|l|}{ Interventions } & \multirow{2}{*}{$\begin{array}{l}\text { Follow- } \\
\text { up }\end{array}$} & \multirow[t]{2}{*}{ Outcomes } & \multirow[t]{2}{*}{ Primary Results } \\
\hline & & & Experimental & Control & & & \\
\hline $\begin{array}{l}\text { Benecke } \\
2001[8]\end{array}$ & $\begin{array}{l}\text { Retrospective } \\
\text { cohort study }\end{array}$ & $\begin{array}{l}\text { Patients } \\
\text { underwent } \\
\text { tympanoplasty }\end{array}$ & $\begin{array}{l}\text { ADM (human-derived), } \\
n=20\end{array}$ & $\begin{array}{l}\text { Autologous } \\
\text { temporalis } \\
\text { fascia, } n=20\end{array}$ & $\begin{array}{l}6 \\
\text { months }\end{array}$ & $\begin{array}{l}\text { Graft success } \\
\text { rate; } \\
\text { Audiometric } \\
\text { tests(ABG) }\end{array}$ & $\begin{array}{l}\text { ADM is a suitable material } \\
\text { for TM grafting }\end{array}$ \\
\hline $\begin{array}{l}\text { Min } \\
2018 \\
{[26]}\end{array}$ & $\begin{array}{l}\text { Retrospective } \\
\text { cohort study }\end{array}$ & $\begin{array}{l}\text { Patients with } \\
\text { tympanic } \\
\text { membrane } \\
\text { perforation who } \\
\text { underwent type I } \\
\text { tympanoplasty }\end{array}$ & $\begin{array}{l}\text { ADM (human-derived) } \\
n=26\end{array}$ & $\begin{array}{l}\text { Autologous } \\
\text { tragal } \\
\text { perichondrium, } \\
n=27\end{array}$ & $\begin{array}{l}3 \\
\text { months }\end{array}$ & $\begin{array}{l}\text { Graft success } \\
\text { rate; } \\
\text { Operation } \\
\text { time; } \\
\text { Postoperative } \\
\text { pain; } \\
\text { Audiometric } \\
\text { tests(ABG,BC) }\end{array}$ & $\begin{array}{l}\text { Tympanoplasty using ADM } \\
\text { can be achieved with similar } \\
\text { postoperative results and less pain. }\end{array}$ \\
\hline $\begin{array}{l}\text { Vos } 2005 \\
{[27]}\end{array}$ & $\begin{array}{l}\text { Retrospective } \\
\text { cohort study }\end{array}$ & $\begin{array}{l}\text { Patients } \\
\text { underwent type I } \\
\text { tympanoplasty } \\
\text { without } \\
\text { mastoidectomy or } \\
\text { ossicular chain } \\
\text { reconstruction }\end{array}$ & $\begin{array}{l}\text { ADM (human-derived) } \\
n=25\end{array}$ & $\begin{array}{l}\text { Autologous } \\
\text { temporalis } \\
\text { fascia, } n=56 ; \\
\text { Autologous } \\
\text { fascia plus } \\
\text { cartilage } \\
\text { reconstruction, } \\
n=33\end{array}$ & $\begin{array}{l}\text { Not } \\
\text { report }\end{array}$ & $\begin{array}{l}\text { Graft success } \\
\text { rate; } \\
\text { Audiometric } \\
\text { tests(ABG); } \\
\text { Complications }\end{array}$ & $\begin{array}{l}\text { ADM is an effective TM graft } \\
\text { when used in type I } \\
\text { tympanoplasty }\end{array}$ \\
\hline $\begin{array}{l}\text { Yang } \\
2019 \\
{[28]}\end{array}$ & $\begin{array}{l}\text { Retrospective } \\
\text { cohort study }\end{array}$ & $\begin{array}{l}\text { Patients of } \\
\text { tympanic } \\
\text { membrane } \\
\text { perforations who } \\
\text { underwent } \\
\text { tympanoplasty }\end{array}$ & $\begin{array}{l}\text { ADM (human-derived) } \\
n=27\end{array}$ & $\begin{array}{l}\text { Autologous } \\
\text { tragal } \\
\text { perichondrium, } \\
n=34\end{array}$ & $\begin{array}{l}6 \\
\text { months }\end{array}$ & $\begin{array}{l}\text { Graft success } \\
\text { rate; } \\
\text { Operation } \\
\text { time; } \\
\text { Audiometric } \\
\text { tests(ABG) }\end{array}$ & $\begin{array}{l}\text { ADM can be recommended as an } \\
\text { attractive alternative to cartilage } \\
\text { grafts }\end{array}$ \\
\hline $\begin{array}{l}\text { Fu } 2017 \\
{[29]}\end{array}$ & $\begin{array}{l}\text { Retrospective } \\
\text { cohort study }\end{array}$ & $\begin{array}{l}\text { Chronic } \\
\text { suppurative otitis } \\
\text { media patients } \\
\text { underwent type I } \\
\text { tympanoplasty }\end{array}$ & $\begin{array}{l}\text { ADM (human-derived), } \\
n=32\end{array}$ & $\begin{array}{l}\text { Autologous } \\
\text { temporalis } \\
\text { fascia, } n=28\end{array}$ & $\begin{array}{l}3 \\
\text { months }\end{array}$ & $\begin{array}{l}\text { Graft success } \\
\text { rate; } \\
\text { Operation } \\
\text { time; } \\
\text { Postoperative } \\
\text { pain } \\
\text { Audiometric } \\
\text { tests(ABG) }\end{array}$ & $\begin{array}{l}\text { The effect of ADM for repairing } \\
\text { tympanic membrane is similar to } \\
\text { the temporalis fascia. }\end{array}$ \\
\hline $\begin{array}{l}\text { Lee } 2018 \\
\text { [22] }\end{array}$ & $\begin{array}{l}\text { Prospective } \\
\text { randomised } \\
\text { controlled } \\
\text { study }\end{array}$ & $\begin{array}{l}\text { Patients who } \\
\text { underwent type I } \\
\text { tympanoplasty for } \\
\text { tympanic } \\
\text { membrane } \\
\text { perforation }\end{array}$ & $\begin{array}{l}\text { ADM (human-derived) } \\
n=27\end{array}$ & $\begin{array}{l}\text { Autologous } \\
\text { tragal } \\
\text { perichondrium, } \\
\mathrm{n}=33\end{array}$ & $\begin{array}{l}6 \\
\text { months }\end{array}$ & $\begin{array}{l}\text { Graft success } \\
\text { rate; } \\
\text { Operation } \\
\text { time; } \\
\text { Postoperative } \\
\text { pain; } \\
\text { Audiometric } \\
\text { tests(ABG,AC, } \\
\text { BC); } \\
\text { Complications }\end{array}$ & $\begin{array}{l}\text { ADM was shown to be an } \\
\text { effective alternative to tragal } \\
\text { perichondrium. }\end{array}$ \\
\hline $\begin{array}{l}\text { Li } 2014 \\
{[23]}\end{array}$ & $\begin{array}{l}\text { Randomised } \\
\text { controlled } \\
\text { study }\end{array}$ & $\begin{array}{l}\text { Middle ear } \\
\text { cholesteatoma } \\
\text { patients } \\
\text { underwent } \\
\text { tympanoplasty for } \\
\text { tympanic } \\
\text { membrane } \\
\text { perforation }\end{array}$ & $\begin{array}{l}\text { ADM (human-derived) } \\
n=30\end{array}$ & $\begin{array}{l}\text { Autologous } \\
\text { temporalis } \\
\text { fascia, } n=22\end{array}$ & $\begin{array}{l}12 \\
\text { months }\end{array}$ & $\begin{array}{l}\text { Graft success } \\
\text { rate; } \\
\text { Audiometric } \\
\text { tests(ABG) }\end{array}$ & $\begin{array}{l}\text { ADM was shown to be an } \\
\text { effective alternative to the } \\
\text { temporalis fascia }\end{array}$ \\
\hline $\begin{array}{l}\text { Raj } 2011 \\
{[24]}\end{array}$ & $\begin{array}{l}\text { Prospective } \\
\text { randomized } \\
\text { unblinded } \\
\text { controlled } \\
\text { trial }\end{array}$ & $\begin{array}{l}\text { chronic } \\
\text { suppurative otitis } \\
\text { media patients } \\
\text { underwent type I } \\
\text { tympanoplasty }\end{array}$ & $\begin{array}{l}\text { ADM (human-derived) } \\
n=20\end{array}$ & $\begin{array}{l}\text { Autologous } \\
\text { temporalis } \\
\text { fascia, } n=20\end{array}$ & $\begin{array}{l}3 \\
\text { months }\end{array}$ & $\begin{array}{l}\text { Graft success } \\
\text { rate; } \\
\text { Operation } \\
\text { time; } \\
\text { Postoperative } \\
\text { pain; } \\
\text { Audiometric } \\
\text { tests(ABG,BC) }\end{array}$ & $\begin{array}{l}\text { ADM as graft material are } \\
\text { comparable to temporalis fascia in } \\
\text { terms of graft uptake and hearing } \\
\text { improvement. }\end{array}$ \\
\hline
\end{tabular}


Table 1 Characteristics of the include studies (Continued)

\begin{tabular}{|c|c|c|c|c|c|c|c|}
\hline \multirow[t]{2}{*}{ Study } & \multirow[t]{2}{*}{ Design } & \multirow[t]{2}{*}{ Participants } & \multicolumn{2}{|l|}{ Interventions } & \multirow{2}{*}{$\begin{array}{l}\text { Follow- } \\
\text { up }\end{array}$} & \multirow[t]{2}{*}{ Outcomes } & \multirow[t]{2}{*}{ Primary Results } \\
\hline & & & Experimental & Control & & & \\
\hline $\begin{array}{l}\text { Liao } \\
2017 \\
{[25]}\end{array}$ & $\begin{array}{l}\text { Randomised } \\
\text { controlled } \\
\text { study }\end{array}$ & $\begin{array}{l}\text { Chronic } \\
\text { suppurative otitis } \\
\text { media patients } \\
\text { undergoing } \\
\text { tympanoplasty }\end{array}$ & $\begin{array}{l}\text { ADM (human-derived), } \\
n=18\end{array}$ & $\begin{array}{l}\text { Tragus } \\
\text { cartilage- } \\
\text { perichondrium, } \\
n=69 ; \\
\text { Mastoid } \\
\text { process } \\
\text { periosteum, } \\
n=21 ; \\
\text { Temporalis } \\
\text { fascia, } \mathrm{n}=28\end{array}$ & $\begin{array}{l}24 \\
\text { months }\end{array}$ & $\begin{array}{l}\text { Graft success } \\
\text { rate; } \\
\text { Operation } \\
\text { time; } \\
\text { Audiometric } \\
\text { tests(ABG) }\end{array}$ & $\begin{array}{l}\text { ADM is suitable for small and } \\
\text { medium-sized perforation. }\end{array}$ \\
\hline
\end{tabular}

TM Tympanic membrane; ADM Acellular dermal matrix; AC Air conduction BC Bone conduction ABG Air-bone gap

analysis according to the trial design to reduce the heterogeneity of all outcomes. For important outcomes, we performed sensitivity analyses to explore the effect of risk of bias by temporarily excluding studies with a high risk of bias to determine whether this impacted the results. Publication bias was assessed by funnel plots and Egger's test. Egger's linear regression test was used to evaluate asymmetry. Values of $p<0.05$ were considered statistically significant.

\section{Results}

\section{Included studies}

The electronic search initially retrieved 50 articles, 20 of which were retained after removing duplicates. After screening the titles and abstracts, the search identified 12 possibly relevant studies $[8,19-29]$. Based on a review of the full text, three clinical studies were excluded. Two studies did not use autologous grafts as a control group [19, 21], and one study did not focus on TM perforation [20]. Five retrospective cohort studies and four randomized controlled studies with a total of 610 participants were included in the present metaanalysis [8, 22-29]. For further details, see Fig. 1.

All of the included studies used human-derived ADM for TM grafting. Four studies used the temporalis fascia as the control group [8, 23, 24, 29], three used the tragal perichondrium $[22,26,28]$, and two combined multiple autologous grafts as the control group [25, 27]. Three studies only included patients with suppurative otitis media [24, 25, 29], and one study included patients with middle ear cholesteatoma [23]. ,The other studies did not report causes of the participants' TM perforation. One study did not report the length of the follow-up period [27], For the other studies, the follow-up length was 3-24 months. Characteristics of the included studies and participants are reported in Tables 1 and 2.

Table 2 Characteristics of participants

\begin{tabular}{|c|c|c|c|c|c|c|c|c|c|}
\hline Study & Country & $\mathrm{n}$ & $\begin{array}{l}\text { Average } \\
\text { age }\end{array}$ & $\begin{array}{l}\text { Causes of TM } \\
\text { perforation }\end{array}$ & $\begin{array}{l}\text { Mean } \\
\text { perforation } \\
\text { size\% }\end{array}$ & $\begin{array}{l}\text { ADM } \\
\text { derivation }\end{array}$ & $\begin{array}{l}\text { Autologous } \\
\text { grafts }\end{array}$ & $\begin{array}{l}\text { Type of } \\
\text { surgery }\end{array}$ & Anesthesia \\
\hline $\begin{array}{l}\text { Benecke } \\
2001 \text { [8] }\end{array}$ & USA & 40 & $N R$ & NR & NR & human & $\begin{array}{l}\text { Temporalis } \\
\text { fascia }\end{array}$ & $\begin{array}{l}\text { Type } 1 \\
\text { tympanoplasty }\end{array}$ & NR \\
\hline $\begin{array}{l}\text { Min } 2018 \\
{[26]}\end{array}$ & Korea & 53 & 53.2 & NR & $22.90 \%$ & human & $\begin{array}{l}\text { Tragal } \\
\text { perichondrium }\end{array}$ & $\begin{array}{l}\text { Type } 1 \\
\text { tympanoplasty }\end{array}$ & $\begin{array}{l}\text { Local } \\
\text { anesthesia }\end{array}$ \\
\hline $\begin{array}{l}\text { Vos } 2005 \\
{[27]}\end{array}$ & USA & 108 & 20 & NR & $45 \%$ & human & Multiple grafts & $\begin{array}{l}\text { Type } 1 \\
\text { tympanoplasty }\end{array}$ & $\begin{array}{l}\text { General } \\
\text { anesthesia }\end{array}$ \\
\hline $\begin{array}{l}\text { Yang } 2019 \\
{[28]}\end{array}$ & China & 61 & 29.2 & NR & NR & human & $\begin{array}{l}\text { Tragal } \\
\text { perichondrium }\end{array}$ & $\begin{array}{l}\text { Type } 1 \\
\text { tympanoplasty }\end{array}$ & $\begin{array}{l}\text { General } \\
\text { anesthesia }\end{array}$ \\
\hline $\begin{array}{l}\text { Fu } 2017 \\
{[29]}\end{array}$ & China & 60 & 31.5 & $\begin{array}{l}\text { Chronic suppurative } \\
\text { otitis media }\end{array}$ & NR & human & $\begin{array}{l}\text { Temporalis } \\
\text { fascia }\end{array}$ & $\begin{array}{l}\text { Type } 1 \\
\text { tympanoplasty }\end{array}$ & $\begin{array}{l}\text { Local } \\
\text { anesthesia }\end{array}$ \\
\hline $\begin{array}{l}\text { Lee } 2018 \\
{[22]}\end{array}$ & Korea & 60 & 53.3 & NR & NR & human & $\begin{array}{l}\text { Tragal } \\
\text { perichondrium }\end{array}$ & $\begin{array}{l}\text { Type } 1 \\
\text { tympanoplasty }\end{array}$ & $\begin{array}{l}\text { Local } \\
\text { anesthesia }\end{array}$ \\
\hline Li 2014 [23] & China & 52 & 53 & $\begin{array}{l}\text { Middle ear } \\
\text { cholesteatoma }\end{array}$ & NR & human & $\begin{array}{l}\text { Temporalis } \\
\text { fascia }\end{array}$ & $\begin{array}{l}\text { Type } 1 \\
\text { tympanoplasty }\end{array}$ & $\begin{array}{l}\text { General } \\
\text { anesthesia }\end{array}$ \\
\hline $\begin{array}{l}\text { Raj } 2011 \\
{[24]}\end{array}$ & India & 40 & NR & $\begin{array}{l}\text { Chronic suppurative } \\
\text { otitis media }\end{array}$ & NR & human & $\begin{array}{l}\text { Temporalis } \\
\text { fascia }\end{array}$ & $\begin{array}{l}\text { Type } 1 \\
\text { tympanoplasty }\end{array}$ & $\begin{array}{l}\text { Local } \\
\text { anesthesia }\end{array}$ \\
\hline $\begin{array}{l}\text { Liao } 2017 \\
{[25]}\end{array}$ & China & 136 & 41 & $\begin{array}{l}\text { Chronic suppurative } \\
\text { otitis media }\end{array}$ & NR & human & Multiple grafts & $\begin{array}{l}\text { Type } 1 \\
\text { tympanoplasty }\end{array}$ & NR \\
\hline
\end{tabular}

TM Tympanic membrane; ADM Acellular dermal matrix; NR Not report 
Table 3 Risk of bias assessment of retrospective cohort studies

\begin{tabular}{|c|c|c|c|c|c|c|c|c|}
\hline \multirow[t]{2}{*}{ stduy } & \multicolumn{4}{|c|}{ Selection } & \multirow{2}{*}{$\begin{array}{l}\text { Comparability } \\
\text { Item } 5\end{array}$} & \multicolumn{3}{|c|}{ Outcome } \\
\hline & Item 1 & Item 2 & Item 3 & Item 4 & & Item 6 & Item 7 & Item 8 \\
\hline Benecke 2001 [8] & & is & is & $\dot{s}$ & is & & 㶦 & is \\
\hline Min 2018 [26] & $\dot{\omega}$ & is & $i$ & $\dot{\omega}$ & 论㑔 & is & 幽 & 放 \\
\hline Vos 2005 [27] & $\dot{s}$ & is & $\hat{s}$ & 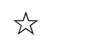 & 论柁 & is & & \\
\hline Yang 2019 [28] & $\hat{s}$ & is & $\hat{s}$ & 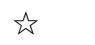 & 论柁 & is & 弥 & $\dot{s}$ \\
\hline Fu 2017 [29] & $\hat{s}$ & is & $i$ & $\hat{s}$ & is & is & 弥 & $i$ \\
\hline
\end{tabular}

Item 1: Representativeness of the exposed cohort

Item 2: Selection of the non - exposed cohort

Item 3: Ascertainment of exposure

Item 4: Demonstration that outcome of interest was not present at start of study

Item 5: Comparability of cohorts on the basis of the design or analysis

Item 6: Assessment of outcome

Item 7: Was follow-up long enough for outcomes to occur

Item 8: Adequacy of follow up of cohorts

\section{Risk of bias}

For retrospective cohort studies, we assessed the risk of bias in terms of case selection, comparability, and the adequacy of outcome. The reporting quality of two studies was determined to be adequate $[26,28]$. One study was assessed as having a high risk of case selection bias because of no description of derivation of the cohort was provided [8]. Two studies were assessed as having a high risk of comparability bias because the authors only reported one factor of the participants and no additional factor for the study design control $[8,29]$. Two studies were assessed as having a high risk of adequacy of outcome bias (one study because no details of the assessment of outcome were reported [8], and one study because it did not report the length of the follow-up period [27]). Further details of the risk of assessment bias for the retrospective cohort studies are reported in Table 3.

For randomized controlled studies, we assessed the risk of bias in terms of allocation sequence generation, blinding, the incomplete reporting of outcome data, and selective reporting. Overall, the methodological quality of the randomized controlled studies was inadequate. None of the included randomized controlled studies adequately provided methodological information. Only one study reported the method that was used to generate the random sequence [22]. One study was assessed as having a high risk of performance bias because it was an unblinded controlled trial [24]. However, all of the studies reported complete outcome data. A summary of methodological quality for the randomized controlled studies is provided in Table 4.

\section{Heterogeneity assessment}

$\mathrm{ChI}^{2}$ statistic was used to assess heterogeneity. We regarded heterogeneity as substantial if $\mathrm{I}^{2}>50 \%$. Galbraith plots were used to explore potential sources of heterogeneity. Galbraith plots provides a graphical display to get a visual impression of the amount of heterogeneity from a meta-analysis. For each study is plotted according $\mathrm{z}$ statistic, and the regression line constrained through the origin, with its $95 \%$ confidence interval, when the plots of studies out of the confidence bounds, indicate the studies may be the source of heterogeneity. According to the assessment, there is heterogeneity in the outcomes of surgery time and immediately postsurgery pain, and there is a low risk of heterogeneity in other outcomes. Further details of the heterogeneity assessment reported in Fig. 2 and Table 5.

Table 4 Risk of bias assessment of randomised controlled studies

\begin{tabular}{|c|c|c|c|c|c|c|c|}
\hline \multirow[t]{2}{*}{ stduy } & \multicolumn{2}{|c|}{ Selection bias } & \multirow{2}{*}{$\begin{array}{l}\text { Performance bias } \\
\text { Item } 3\end{array}$} & \multirow{2}{*}{$\begin{array}{l}\text { Detection bias } \\
\text { Item } 4\end{array}$} & \multirow{2}{*}{$\begin{array}{l}\text { Attrition bias } \\
\text { Item } 5\end{array}$} & \multirow{2}{*}{$\begin{array}{l}\text { Reporting bias } \\
\text { Item } 6\end{array}$} & \multirow{2}{*}{$\begin{array}{l}\text { Other bias } \\
\text { Item } 7\end{array}$} \\
\hline & Item 1 & Item 2 & & & & & \\
\hline Lee 2018 [22] & Low risk & Unclear risk & Unclear risk & Unclear risk & Low risk & Unclear risk & Unclear risk \\
\hline Li 2014 [23] & Unclear risk & Unclear risk & Unclear risk & Unclear risk & Low risk & Unclear risk & Unclear risk \\
\hline Raj 2011 [24] & Unclear risk & Unclear risk & High risk & High risk & Low risk & Unclear risk & Unclear risk \\
\hline Liao 2017 [25] & Unclear risk & Unclear risk & Unclear risk & Unclear risk & Low risk & Unclear risk & Unclear risk \\
\hline
\end{tabular}

Item 1: Random sequence generation;

Item 2: Allocation concealment;

Item 3: Blinding of participants and personnel:

Item 4: Blinding of outcome assessment;

Item 5: Incomplete outcome data;

Item 6: Selective reporting

Item 7: Bias due to problems not covered by [1] to [6] above 

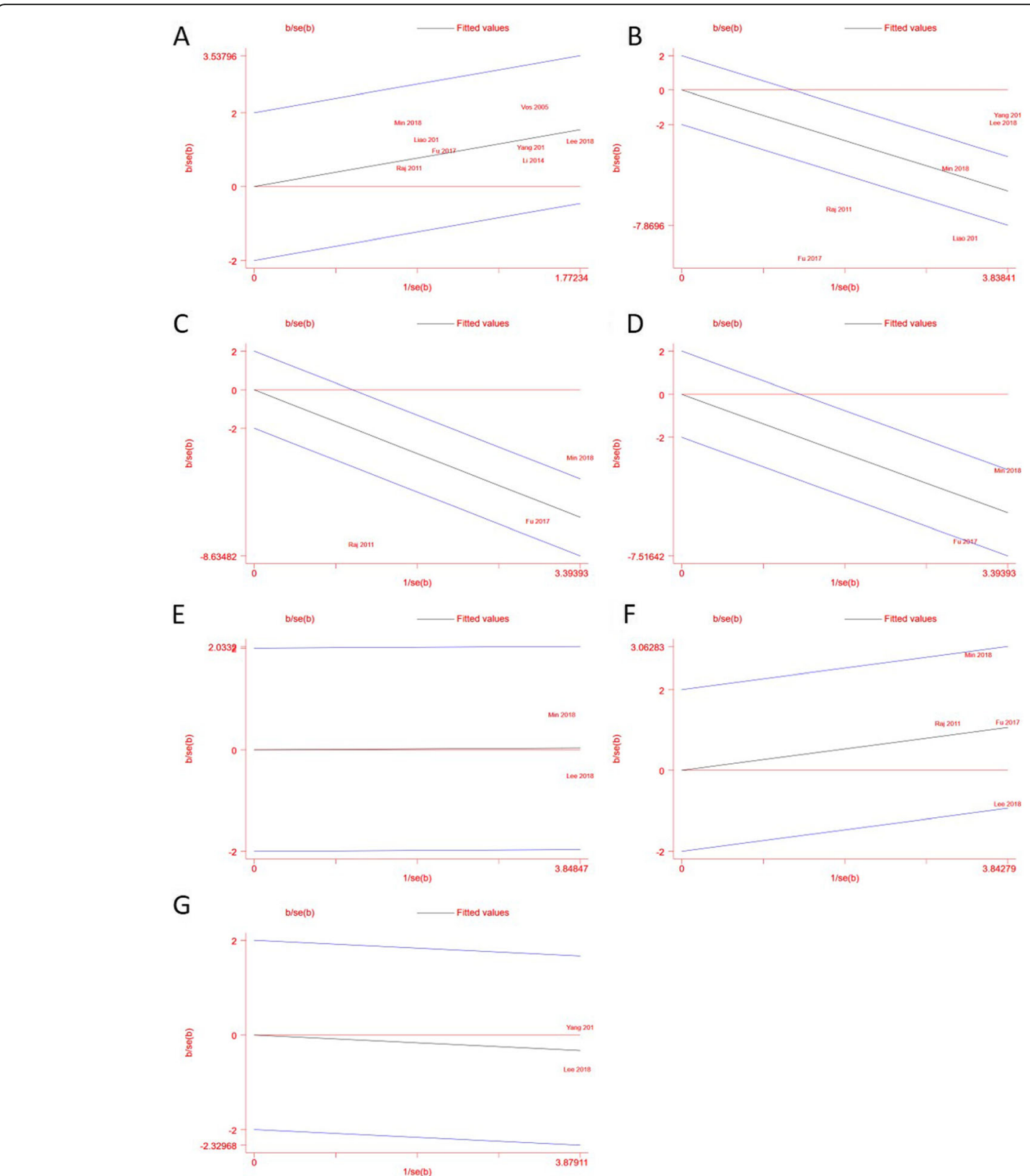

Fig. 2 Galbraith plots of outcomes. Heterogeneity assessment. Galbraith plots of pooled outcomes, study plots outside the $95 \%$ confidence interval indicate heterogeneity. (a) Graft success rate; (b) Operation time; (c) Immediate postoperative pain, study Raj 2011 included; (d) Immediate postoperative pain, study Raj 2011 excluded; (e) Bone conduction; (f) Air-bone gap; (g) Air-bone gap reduction. The outcomes of pain one day after surgery and air conduction are unavailable due to insufficient number of studies

\section{Publication bias}

Publication bias was assessed by funnel plots and Egger's test. Funnel plots are used to examine whether the results of a meta-analysis may have been affected by publication or other types of bias, and in the absence of bias the plot will resemble a symmetrical inverted funnel. Egger's linear regression test was used to evaluate asymmetry. According to egger's test, there is publication bias in the outcomes of graft success rate and average ABG.
Further details of the publication bias assessment reported in Fig. 3 and Table 5.

\section{Effects of interventions}

\section{Graft success rate}

All of the included studies reported the graft success rate, with a total of 610 participants [8, 22-29]. A forest plot of the graft success rate is shown in Fig. 4. No significant difference in graft success rate was found 
Table 5 Heterogeneity and publication bias assessment

\begin{tabular}{llll}
\hline Outcomes & $\mathbf{I}^{\mathbf{2}}$ & Potential source of heterogeneity & Egger's test \\
\hline Graft success rate & $0 \%$ & none & $p=0.835$ \\
Surgery time & $90 \%$ & Fu 2017 [29]; Yang 2019 [28]; Lee 2018 [22]; Liao 2017 [25]; $p=0.016$ & $p=0.178$ \\
Postoperative pain (immediately postsurgery) & $91 \%$ & Raj 2011 [24] & Not applicable \\
Postoperative pain (1 day postsurgery) & Not applicable & Not applicable & Not applicable \\
Hearing results (average AC) & Not applicable & Not applicable & Not applicable \\
Hearing results (average BC) & $0 \%$ & none & $p=0.522$ \\
Hearing results (average ABG) & $38 \%$ & none & Not applicable \\
Hearing results (ABG reduction) & $0 \%$ & none & Not applicable \\
Complications & Not applicable & Not applicable & .
\end{tabular}

Not applicable: the assessment is not possible because of the insufficient number of included studies

between the ADM group and autologous graft group (OR: $0.71[0.39,1.29], p=0.26$ ). The subgroup analysis showed no significant difference between the retrospective cohort studies and randomized controlled studies $(p=0.25)$.

\section{Surgery time}

Seven studies reported the surgery time [22, 24-29]. However, one of these studies only reported the average surgery time and did not report the SD [27]. Therefore, the outcomes of six studies were pooled, with a total of 435 participants. The forest plot of surgery time is shown in Fig. 5. A significant reduction of surgery time was found in the ADM group compared with the autologous graft group (MD: - 16.14 [-21.22, - 11.07], $p<$ $0.00001)$. The subgroup analysis showed no significant difference between the two groups $(p=0.58)$.

\section{Postoperative pain}

Three studies reported postoperative pain [24, 26, 29]. The forest plot of postoperative pain is shown in Fig. 6 . Two studies reported immediate postoperative pain, indicated by VAS pain scores [24, 29]. One study reported pain scores both immediately postsurgery and 1 day postsurgery [26]. All three studies used type 1 tympanoplasty and administered local anesthesia. Two studies used the temporalis fascia for autologous grafts, and one study used the tragal perichondrium for autologous grafts. A significant reduction of postoperative pain was found in the ADM group compared with the autologous graft group (MD: - 2.57 [- 3.57, - 1.58], $p<0.00001$; Fig. 6a). Only one study reported pain levels 1 day postsurgery, with a significant reduction of VAS pain scores in the ADM group (MD: -0.70 [- 1.29, -0.11$], p=0.02$; Fig. $6 \mathrm{~b}$ ).

\section{Hearing results}

The forest plot of the hearing results is shown in Fig. 7. Based on our inclusion and exclusion criteria, all of the studies in which audiologic data were collected involved type 1 tympanoplasties and no ossicular chain reconstructions. One study reported AC thresholds [22]. No significant difference in AC thresholds was found between the ADM group and autologous graft group (MD: 0.39 [-11.49, 3.69], $p=$ 0.52; Fig. 7a). Two studies reported BC thresholds $[22,26]$. No significant difference in BC thresholds was found between the ADM group and autologous graft group (MD: 0.35 [-5.50, 6.20], $p=0.91$; Fig. 7b). Seven studies reported the ABG [22-26, 28, 29]. Three studies reported the average ABG as means and SDs [24, 26, 29], One study reported a reduction of the ABG [28], and one study reported both the average $\mathrm{ABG}$ and reduction of the $\mathrm{ABG}$ [22]. The other two studies reported the ABG as grading data $[23,25]$. Therefore, five studies were included in this analysis. The average ABG significantly increased in the ADM group compared with the autologous graft group (MD: $1.11[0.28,1.93], p=$ 0.008). The subgroup analysis of retrospective cohort studies showed a more significant reduction of the ABG in the ADM group (MD: 1.26 [0.38, 2.15], $p=0.005)$. However, a contradictory result from the randomized controlled studies indicated no significant difference in the average ABG between the ADM group and autologous graft group (MD: 0.12 [-2.64, 2.39], $p=0.92$; Fig. 7c). No significant difference in the ABG reduction was found between the ADM group and autologous graft group (MD: -0.59 [-3.81, 1.19], $p=0.51$; Fig. 7d).

\section{Complications}

Two studies reported postoperative complications [22, 27]. The forest plot of complications is shown in Fig. 8. No significant difference in the rate of complications was found between the ADM group and autologous graft group (OR: 1.23 [0.07, 20.64], $p=0.89$ ). 
A

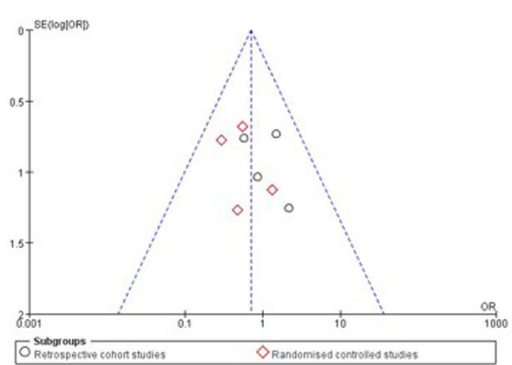

C

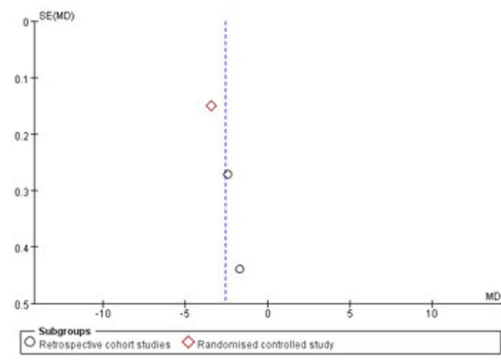

E

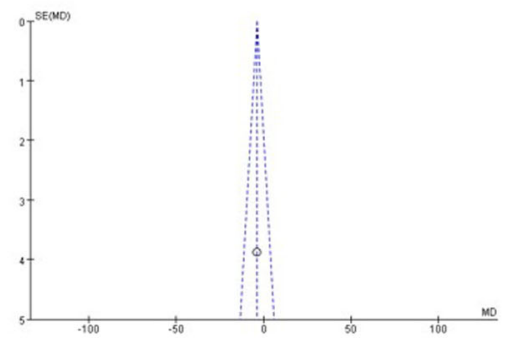

G

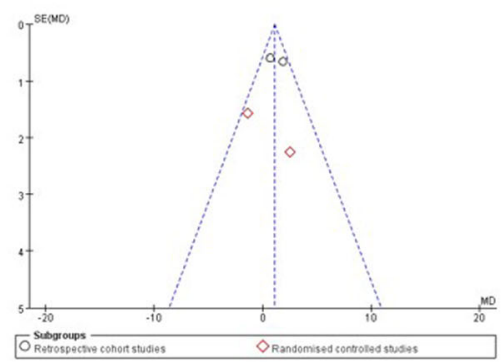

B

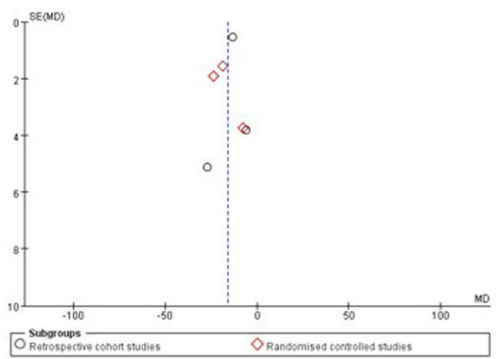

D

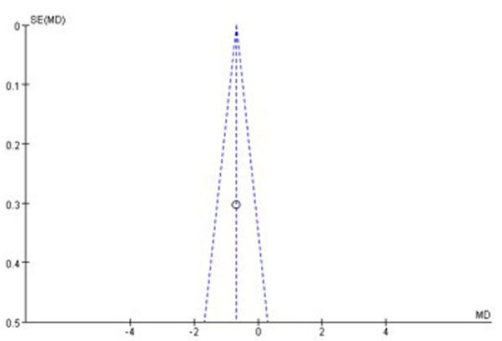

F

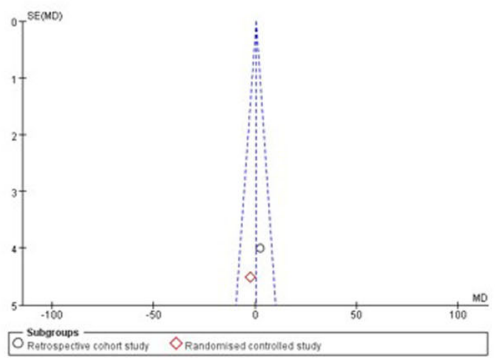

$\mathrm{H}$

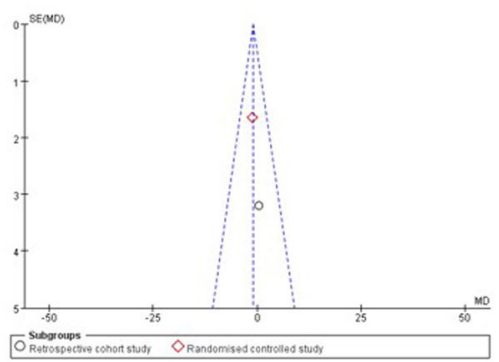

Fig. 3 Funnel plots of outcomes. Publication bias assessment. Funnel plots of outcomes, Egger's linear regression test was used to evaluate asymmetry, and $\mathrm{P}<0.05$ was set as the level of significance. (a) Graft success rate, $p=0.288$; (b) Operation time, $p=0.016$; (c) Immediate postoperative pain, $p=0.178$; (d) Pain one day after surgery, insufficient observations for Egger's test; (e) Air conduction, insufficient observations for Egger's test; (f) Bone conduction, insufficient observations for Egger's test; (g) Air-bone gap, $p=0.522$; (h) Air-bone gap reduction, insufficient observations for egger's test

\section{Discussion}

The present systematic review and meta-analysis included nine studies with a total of 610 participants. We found that compared with autologous grafts, ADM was an effective alternative as a material for TM grafting, with a similar graft success rate and postoperative hearing results. Furthermore, ADM may also significantly reduce surgery time and postoperative pain.

Although no significant difference in the graft success rate was found between the ADM group and autologous graft group, the success rate in retrospective cohort studies (OR: 1.02 [0.43, 2.39]) was slightly higher than in 


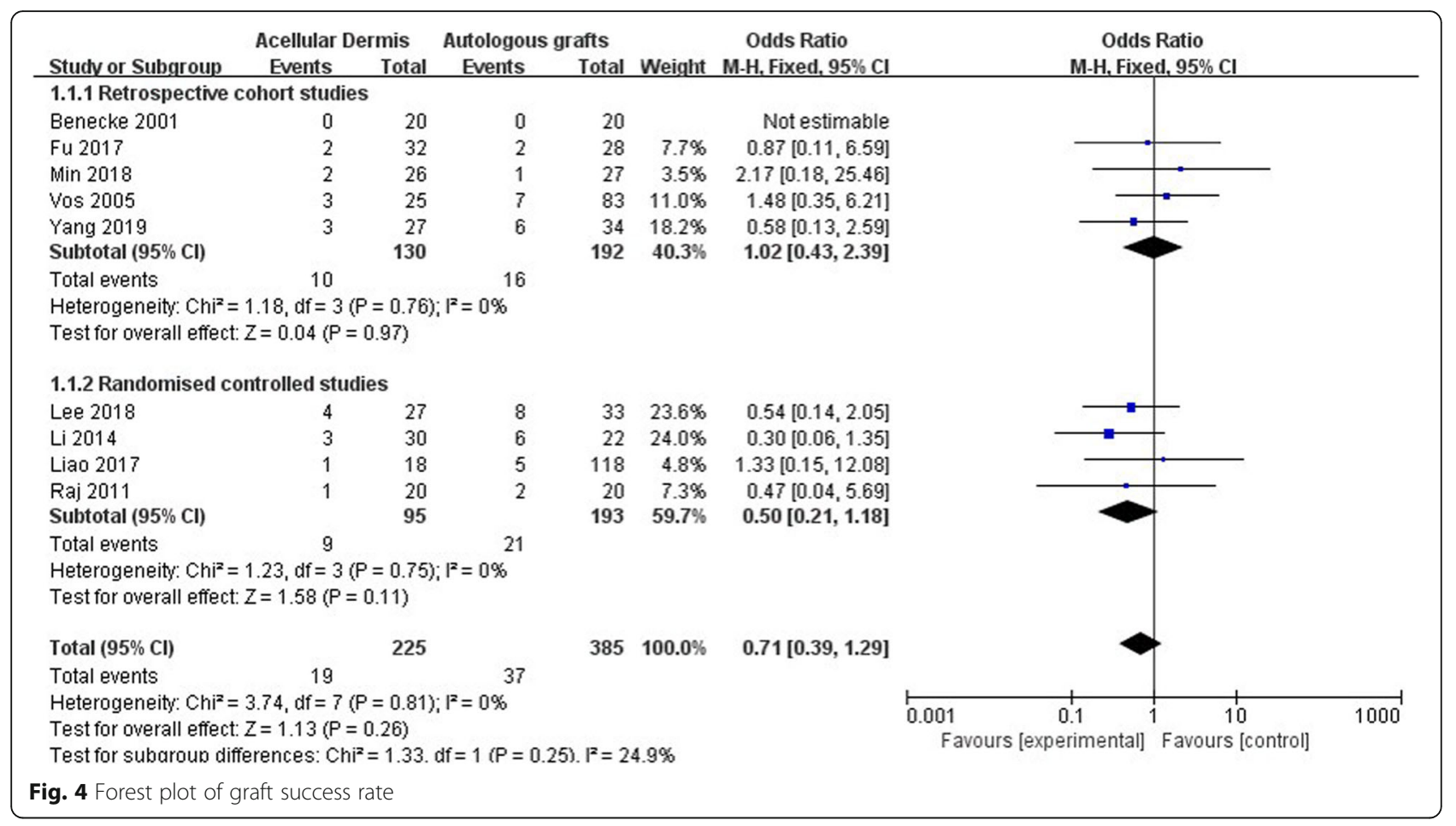

randomized controlled studies (OR: $0.50[0.21,1.18]$ ). We investigated the source of this difference, but it did not appear to derive from participant or surgery factors, such as age, type of graft, and surgical technique. We also explored the impact of the size and location of TM perforations on the graft success rate, but the included studies rarely reported relevant information about perforations. One study showed that graft success rates were not significantly different with regard to size or location of the perforations [22]. Another study reported that the graft success rate was higher for small perforations [28]. Because of the limited patient information that was available in the studies, appropriate case selection for the use of ADM is unclear. Additionally, compared with randomized controlled studies, retrospective cohort studies may have potential case selection bias and thus may be a reason why retrospective cohort studies have a slightly higher graft success rate than randomized controlled studies.

A significant reduction of surgery time was found in the ADM group compared with the autologous graft group. Although a high risk of heterogeneity was found among the included studies, this heterogeneity did not appear to be attributable to any one study. All of the studies reported that the use of ADM can significantly shorten tympanoplasty surgery time. Using autologous grafts as material for tympanoplasty usually requires harvesting grafts from tissue first. Compared with autologous grafts, ADM is advantageous because of its direct use and relatively straightforward surgery. Procedures for harvesting and preparing grafts are unnecessary when using ADM, thus shortening surgery times.

Compared with the autologous graft group, postoperative pain was significantly lower in the ADM group. $\mathrm{Pa}$ tients who receive autologous grafts to repair TM perforations require additional incisions. The use of ADM can avoid external skin incisions and soft tissue dissection compared with autologous grafts. The reduction of pain may result from the absence of these incisions. Immediate postoperative pain can be significantly influenced by the specific surgical approach, the use of local anesthesia, and medications that are administered during recovery before self-reporting pain on VASs. However, although the three studies that were included in the analysis all reported the application of local anesthesia before surgery, these studies did not provide information about the surgical approach or medications.

When comparatively evaluating auditory function, differences between $\mathrm{AC}$ thresholds, $\mathrm{BC}$ thresholds, and the $A B G$ are usually measured before and after surgery. In the present study, the average ABG significantly increased in the ADM group compared with the autologous graft group. However, this increase appeared to derive from bias in one of the studies [26]. When data from this study were excluded, the total MD decreased from $1.11(0.28,1.93, p=0.08)$ to $0.56(-0.51,1.63$, $p=0.31)$, the $\mathrm{I}^{2}$ decreased from $38 \%(p=0.18)$ to $16 \%$ $(p=0.30)$, and the overall effect decreased from 2.64 


\begin{tabular}{|c|c|c|c|c|c|c|c|c|c|c|c|}
\hline \multirow[b]{2}{*}{ Study or Subgroup } & \multicolumn{3}{|c|}{ Acellular Dermis } & \multicolumn{3}{|c|}{ Autologous grafts } & \multirow[b]{2}{*}{ Weight } & \multirow{2}{*}{$\begin{array}{l}\text { Mean Difference } \\
\text { IV, Random, } 95 \% \mathrm{Cl}\end{array}$} & \multirow{2}{*}{\multicolumn{3}{|c|}{$\begin{array}{l}\text { Mean Difference } \\
\text { IV. Random, } 95 \% \mathrm{Cl}\end{array}$}} \\
\hline & Mean & SD & Total & Mean & SD & Total & & & & & \\
\hline \multicolumn{12}{|c|}{ 2.1.1 Retrospective cohort studies } \\
\hline Fu 2017 & 26.11 & 1.46 & 32 & 39.34 & 2.5 & 28 & $20.9 \%$ & $-13.23[-14.29,-12.17]$ & = & & \\
\hline $\operatorname{Min} 2018$ & 65.3 & 20.5 & 26 & 92.3 & 16.5 & 27 & $11.5 \%$ & $-27.00[-37.04,-16.96]$ & - & & \\
\hline Yang 2019 & 68.93 & 14.94 & 27 & 75 & 14.7 & 34 & $14.4 \%$ & $-6.07[-13.56,1.42]$ & & & \\
\hline Subtotal $(95 \% \mathrm{Cl})$ & & & 85 & & & 89 & $46.9 \%$ & $-14.58[-22.86,-6.29]$ & & & \\
\hline \multicolumn{12}{|c|}{$\begin{array}{l}\text { Heterogeneity: } \text { Tau }^{2}=41.96 ; \mathrm{Ch}^{2}=10.73, \mathrm{df}=2(P=0.005) ; \mathrm{l}^{2}=81 \% \\
\text { Test for overall effect: } Z=3.45(P=0.0006)\end{array}$} \\
\hline \multicolumn{12}{|c|}{ 2.1.2 Randomised controlled studies } \\
\hline Lee 2018 & 27.4 & 13.2 & 27 & 35.2 & 15.6 & 33 & $14.7 \%$ & $-7.80[-15.09,-0.51\}$ & $\Rightarrow$ & & \\
\hline Liao 2017 & 48 & 7.2 & 18 & 72 & 9.4 & 118 & $18.9 \%$ & $-24.00[-27.73,-20.27]$ & - & & \\
\hline Raj 2011 & 28.15 & 3.5 & 20 & 47.1 & 6.1 & 20 & $19.5 \%$ & $-18.95[-22.03,-15.87]$ & $=$ & & \\
\hline Subtotal $(95 \% \mathrm{Cl})$ & & & 65 & & & 171 & $53.1 \%$ & $-17.67[-24.62,-10.71]$ & - & & \\
\hline \multicolumn{12}{|c|}{$\begin{array}{l}\text { Heterogeneity: } \text { Tau }^{2}=31.76 ; \mathrm{Chi}^{2}=15.56, \mathrm{df}=2(P=0.0004) ; I^{2}=87 \% \\
\text { Test for overall effect: } Z=4.98(P<0.00001)\end{array}$} \\
\hline \multirow{2}{*}{\multicolumn{4}{|c|}{$\begin{array}{l}\text { Total }(95 \% \mathrm{Cl}) \\
\text { Heterogeneity: } \text { Tau }^{2}=31.87 ; \mathrm{Ch}^{2}=52.43 \text {, df }= \\
\text { Test for overall effect } Z=6.23(P=0.00001) \\
\text { Test for subaroun differences: } \mathrm{Chi}^{2}=0.31 \text {. df }\end{array}$}} & \multicolumn{4}{|c|}{$\begin{aligned} & 260 \quad 100.0 \% \\
&=5(P \leqslant 0.00001) ; F^{2}=90 \%\end{aligned}$} & $-16.14[-21.22,-11.07]$ & $\bullet$ & & \\
\hline & & & & $\begin{array}{l}=5(P \& \\
=1(P=\end{array}$ & $\begin{array}{l}0.00001 \\
0.58) .1^{2}\end{array}$ & $\begin{array}{l}; F^{2}=90 \\
=0 \%\end{array}$ & & & $\begin{array}{ccc}1 & 1 & 1 \\
-100 & -50 & 0 \\
\text { Favours [experimental] }\end{array}$ & $\begin{array}{cc}1 & 1 \\
\text { Favours [control] }\end{array}$ & 100 \\
\hline Fig. 5 Forest plot of & peratio & on tim & & & & & & & & & \\
\hline
\end{tabular}

$(p=0.008)$ to $1.02(p=0.31)$. The ABG reduction analysis, which did not exclude this study, indicated no significant difference in ABG changes between the ADM group and autologous graft group. Additionally, the ABG value can vary not only according to a decrease in the mere sound conduction component by reducing the $\mathrm{AC}$ threshold but also according to changes in the $\mathrm{BC}$ threshold before and after surgery [30-32]. However, only one study reported both the BC threshold and ABG
[26]. One study reported the AC threshold, BC threshold, and ABG [22]. The frequencies that were tested for pure-tone audiography were also not consistent among the included studies.

Only two studies reported postoperative complications [22, 27], and only two cases of myringitis were reported in one of these studies [22]. No significant difference in complications was found between the ADM group and autologous graft group.

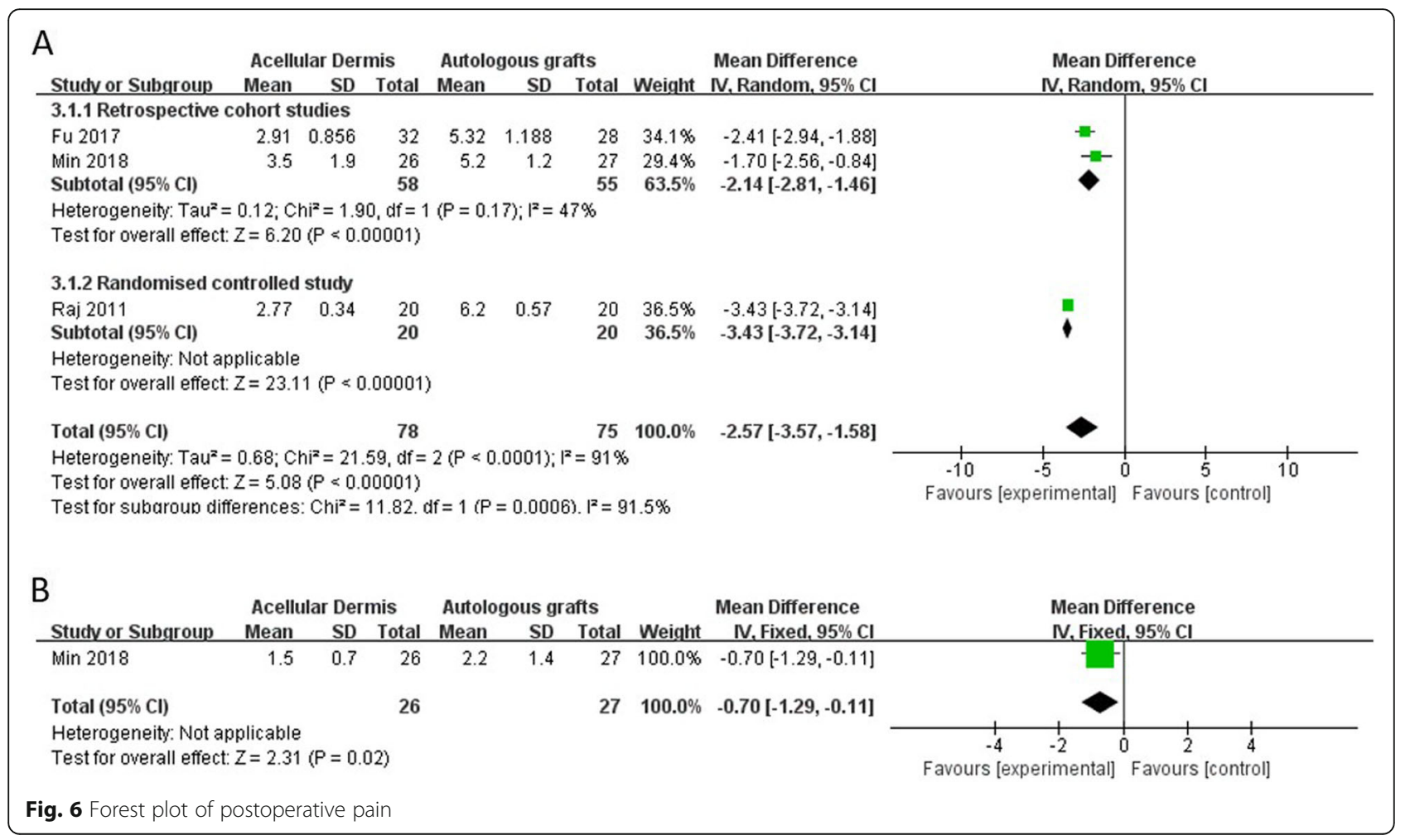



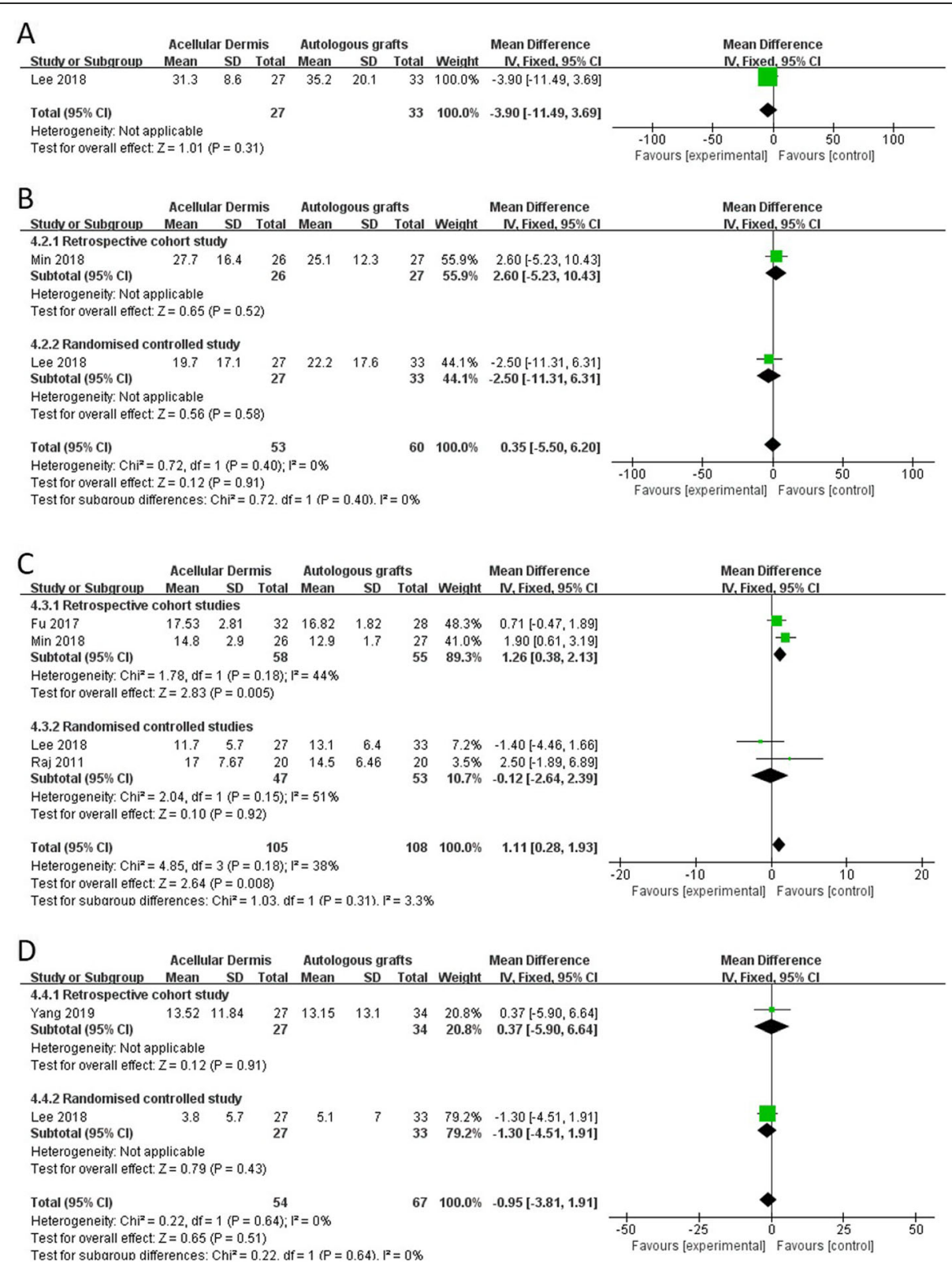

Fig. 7 Forest plot of hearing results

\section{Limitations}

The present meta-analysis has limitations, such as the heterogeneity of some outcomes, and the studies did not distinguish pure-tone audiography data at different frequencies. The main limitation, however, was the high risk of bias of the included studies, especially for randomized controlled studies. More adequately designed clinical trials should be performed in the future to generate solid evidence that may be useful for both clinicians and patients. In addition to the clinical and audiological outcome parameters, further studies should also consider patient-related aspects, such as health-related quality of life, after tympanoplasty [33, 34].

\section{Conclusions}

The present systematic review and meta-analysis confirmed that ADM might be an effective alternative to autologous grafts for tympanoplasty. The use of ADM appears to achieve similar graft success rates and postoperative hearing results, with shortened surgery times and less pain. However, some of the included studies had rather low methodological quality, and more 


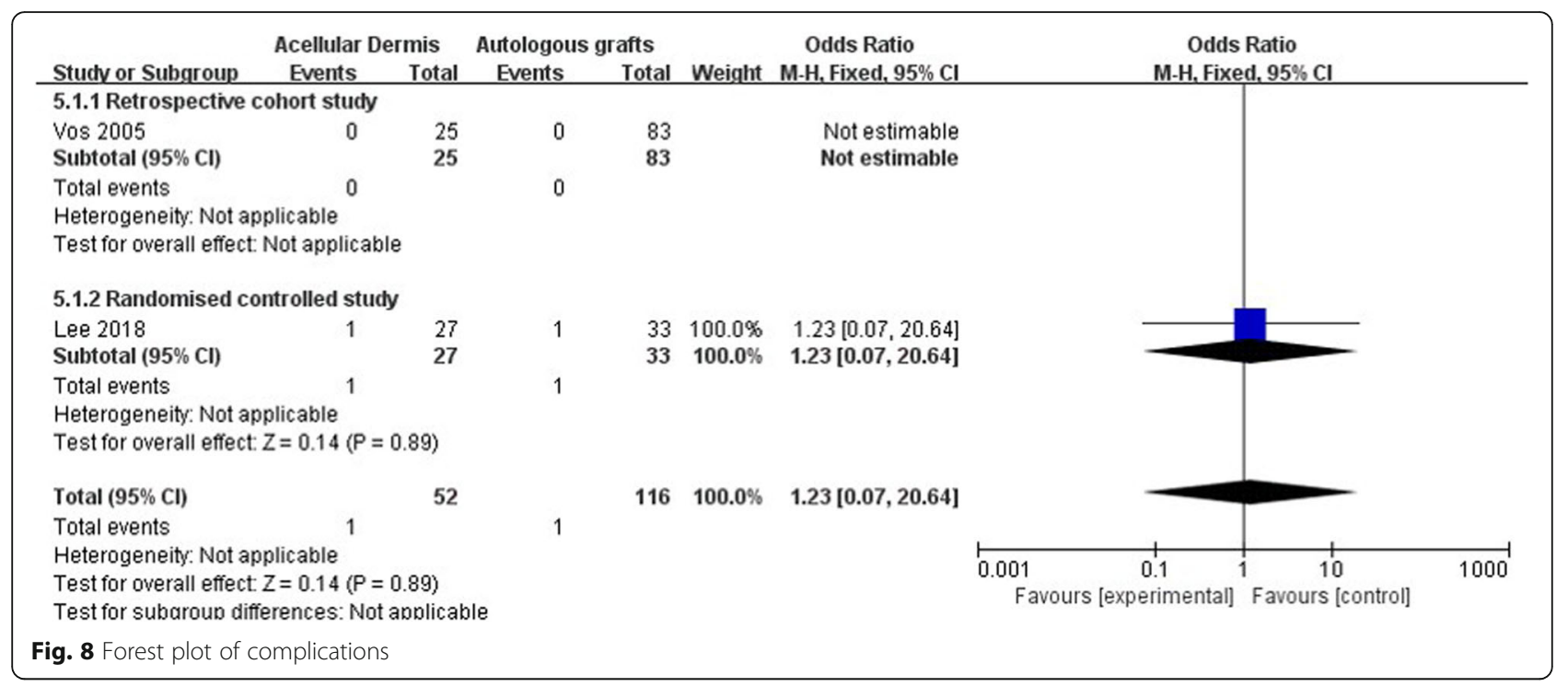

adequately designed clinical trials should be performed in the future.

\section{Abbreviations}

ADM: Acellular dermal matrix; TM: Tympanic membrane; MD: Mean difference; Cl: Confidence intervals; OR: Odds risk; VAS: Visual analogue scale; AC: Air conduction; BC: Bone conduction; ABG: Air-bone gap; HRQoL: Healthrelated quality of life

\section{Supplementary Information}

The online version contains supplementary material available at https://doi. org/10.1186/s40463-021-00518-w.

\section{Additional file 1.}

\section{Acknowledgements}

Not applicable.

\section{Authors' contributions}

Xia Sun and Ning Yang searched literature and extract data. Shan Xu analyzed the data, and was a major contributor in writing the manuscript. Aihui Yan revised the article and final approval of the version. The author(s) read and approved the final manuscript.

\section{Funding}

None.

\section{Availability of data and materials}

Not applicable.

\section{Declarations}

Ethics approval and consent to participate

Not applicable.

\section{Consent for publication \\ Not applicable.}

\section{Competing interests}

The authors declare that they have no competing interests.
Received: 2 January 2021 Accepted: 12 May 2021

Published online: 06 July 2021

\section{References}

1. Seonwoo H, Shin B, Jang KJ, Lee M, Choo OS, Park SB, et al. Epidermal growth factor-releasing radially aligned electrospun Nanofibrous patches for the regeneration of chronic tympanic membrane perforations. Adv Healthc Mater. 2019;8(2):e1801160. https://doi.org/10.1002/adhm.201801160.

2. Downey TJ, Champeaux AL, Silva AB. AlloDerm tympanoplasty of tympanic membrane perforations. Am J Otolaryngol. 2003;24(1):6-13. https://doi.org/1 0.1053/ajot.2003.5

3. Zollner F. The principles of plastic surgery of the sound-conducting apparatus. J Laryngol Otol. 1955;69(10):637-52. https://doi.org/10.1017/S0022215100051240.

4. Pradhan P, Anant A, Venkatachalam VP. Comparison of temporalis fascia and full-thickness cartilage palisades in type-I underlay Tympanoplasty for large/subtotal perforations. Iran J Otorhinolaryngol. 2017;29(91):63-8.

5. Djalilian HR. Revision tympanoplasty using scar tissue graft. Otol Neurotol. 2006;27(2):131-5. https://doi.org/10.1097/01.mao.0000190462.50755.f2.

6. Dundar R, Kulduk E, Soy FK, Aslan M, Yukkaldiran A, Ciftci MA. Boomerangshaped Chondro-Perichondral graft versus temporalis muscle fascia graft: which one is to be trusted? Indian J Otolaryngol Head Neck Surg. 2016; 68(3):339-44. https://doi.org/10.1007/s12070-015-0825-8.

7. Mandour MF, Elsheikh MN, Khalil MF. Platelet-rich plasma fat graft versus cartilage perichondrium for repair of medium-size tympanic membrane perforations. Otolaryngol Head Neck Surg. 2019;160(1):116-21. https://doi. org/10.1177/0194599818789146.

8. Benecke JE Jr. Tympanic membrane grafting with alloderm. Laryngoscope. 2001;111(9):1525-7. https://doi.org/10.1097/00005537-200109000-00007.

9. Lou ZC. Endoscopic cartilage myringoplasty with the removal of a small rim of the external auditory canal to repair marginal perforations. J Otolaryngol Head Neck Surg. 2020;49(1):13 Endoscopic myringoplasty: comparison of double layer cartilage-perichondrium graft and single fascia grafting.

10. Lou ZC. Endoscopic myringoplasty: comparison of double layer cartilageperichondrium graft and single fascia grafting. J Otolaryngol Head Neck Surg. 2020;49(1):40. https://doi.org/10.1186/s40463-020-00440-7.

11. Ozdamar K, Sen A. Comparison of the anatomical and functional success of fascia and perichondrium grafts in transcanal endoscopic type 1 tympanoplasty. J Otolanyngol Head Neck Surg. 2019;48(1):67. https://doi.org/10.1186/s40463-019-0386-z.

12. Takami Y, Yamaguchi R, Ono S, Hyakusoku H. Clinical application and histological properties of autologous tissue-engineered skin equivalents using an acellular dermal matrix. J Nippon Med Sch. 2014;81(6):356-63. https://doi.org/10.1272/jnms.81.356.

13. Jansen LA, De Caigny P, Guay NA, Lineaweaver WC, Shokrollahi K. The evidence base for the acellular dermal matrix AlloDerm: a systematic review. Ann Plast Surg. 2013;70(5):587-94. https://doi.org/10.1097/SAP.0b013e3182 $7 \mathrm{a} 2 \mathrm{~d} 23$. 
14. Haynes DS, Vos JD, Labadie RF. Acellular allograft dermal matrix for tympanoplasty. Curr Opin Otolaryngol Head Neck Surg. 2005;13(5):283-6. https://doi.org/10.1097/01.moo.0000172820.97322.8d.

15. Farahani F, Yazdi AK, Ghasemi M, Shariatpanahi E, Kajbafzadeh A-M, Amanpour S. Results of Acellular dermis matrix graft used for Tympanoplasty in Guinea pig model. Iran J Otorhinolaryngol. 2015;27(2):95-100.

16. Johnson A, Mixson C, Munday J. Suitability of formaldehyde-treated acellular dermis for tympanic membrane repair in chinchillas. Otol Neurotol. 2007; 28(6):778-81. https://doi.org/10.1097/MAO.0b013e318064e912.

17. Laidlaw DW, Costantino PD, Govindaraj S, Hiltzik DH, Catalano PJ. Tympanic membrane repair with a dermal allograft. Laryngoscope. 2001;111(4):702-7. https://doi.org/10.1097/00005537-200104000-00025.

18. Spiegel JH, Kessler JL. Tympanic membrane perforation repair with acellular porcine submucosa. Otol Neurotol. 2005;26(4):563-6. https://doi.org/10.1 097/01.mao.0000169636.63440.4e.

19. Fayad JN, Baino T, Parisier SC. Preliminary results with the use of AlloDerm in chronic otitis media. Laryngoscope. 2003;113(7):1228-30. https://doi.org/1 0.1097/00005537-200307000-00022

20. Zang J, Yang B, Feng S, Jiang X. Repair effect of xenogeneic acellular dermal matrix during external auditory canal reconstruction after canal wall down mastoidectomy. Acta Otolaryngol. 2020;140(2):110-5. https://doi.org/10.1 080/00016489.2019.1701705.

21. Zhou J, Yang C. Clinical application of heterogeneous acellular dermal matrix repair membrane for repairing perforation of tympanic membrane. ACTA Universitatis Medicinalis Nanjing. 2011;31(1):94-122.

22. Lee JM, Seo YJ, Shim DB, Lee HJ, Kim SH. Surgical outcomes of tympanoplasty using a sterile acellular dermal allograft: a prospective randomised controlled study. Acta otorhinolaryngologica Italica. 2018;38(6): 554-62. https://doi.org/10.14639/0392-100X-1839.

23. Li J, Tian W, Han M, Xu J, Gao X, Li X. Clinical application of heterogeneous acellular dermal matrix with autologous bone meal in open tympanoplasty. J Clin Otorhinolaryngol Head Neck Surg. 2014;28(19):1465-8.

24. Raj A, Sayal A, Rathore PK, Meher R. Sutureless tympanoplasty using acellular dermis. Am J Otolaryngol. 2011;32(2):96-9. https://doi.org/10.1016/j.amjoto.2 009.10.007.

25. Liao L, Di J, Chen G, Ma Z, Liu Q, Zhang J. Four kinds of tympanic membrane repair materials application in tympanoplasty. Chin Med J. 2017:55(9):96-9.

26. Min J, Kim S-H. Comparison of transcanal endoscopic tympanoplasty with sterile acellular dermal allograft to conventional endaural microscopic tympanoplasty with tragal perichondrium. Am J Otolaryngol. 2018;39(2): 167-70. https://doi.org/10.1016/j.amjoto.2017.11.014.

27. Vos JD, Latev MD, Labadie RF, Cohen SM, Werkhaven JA, Haynes DS. Use of AlloDerm in type I tympanoplasty: a comparison with native tissue grafts. Laryngoscope. 2005;115(9):1599-602. https://doi.org/10.1097/01.mlg.0000172 042.73024.ad.

28. Yang Z, Wu X, Chen X, Huang Y, Fang L, Li X, et al. Comparison of type I tympanoplasty with acellular dermal allograft and cartilage perichondrium. Acta Otolaryngol. 2019;139(10):833-6. https://doi.org/10.1080/00016489.2019.1637541.

29. Fu X, Su R, Feng X, Chen L, Xiong M. Clinical analysis of curative effect of acellular dermal matrix contrast with temporalis fascia in typel tympanoplasty. Chin Arch Otolaryngol Head Neck Surg. 2017;24(8):396-8.

30. Linstrom CJ, Silverman CA, Rosen A, Meiteles LZ. Bone conduction impairment in chronic ear disease. Ann Otol Rhinol Laryngol. 2001;110(5 Pt 1):437-41. https://doi.org/10.1177/000348940111000508.

31. Tuz M, Dogru H, Uygur K, Gedikli O. Improvement in bone conduction threshold after tympanoplasty. Otolaryngol Head Neck Surg. 2000;123(6): 775-8. https://doi.org/10.1067/mhn.2000.111292.

32. Vartiainen E, Seppa J. Results of bone conduction following surgery for chronic ear disease. Eur Arch Otorhinolaryngol. 1997;254(8):384-6. https:// doi.org/10.1007/BF01642555.

33. Epstein RS, Sherwood LM. From outcomes research to disease management: a guide for the perplexed. Ann Intern Med. 1996;124(9):832-7. https://doi.org/10. 7326/0003-4819-124-9-199605010-00008.

34. Guyatt GH, Feeny DH, Patrick DL. Measuring health-related quality of life. Ann Intern Med. 1993;118(8):622-9. https://doi.org/10.7326/0003-4819-1188-199304150-00009.

\section{Publisher's Note}

Springer Nature remains neutral with regard to jurisdictional claims in published maps and institutional affiliations.

Ready to submit your research? Choose BMC and benefit from:

- fast, convenient online submission

- thorough peer review by experienced researchers in your field

- rapid publication on acceptance

- support for research data, including large and complex data types

- gold Open Access which fosters wider collaboration and increased citations

- maximum visibility for your research: over $100 \mathrm{M}$ website views per year

At BMC, research is always in progress.

Learn more biomedcentral.com/submissions 